\title{
「スーパー纎維とその応用」特集
}

\section{全芳香族ポリエステル繊維 ベクトラン}

植田啓三

\section{1.はじめに}

近年，織維を含む各種成型加工用ポリマーとして液晶 ポリマー程内外の関心を集め注目を浴びているポリマー は他にないであろう。その卓越した機械的諸性質，耐熱 性，耐久性等の性能は広汎な市場分野への展開の可能性 を喚起して来た。そして現在迄その市場開発は特に高性 能を要求される宇宙航空, 通信, 構造用各種複合材分野 を始め，ゴム資材，ロープ，各種防護材等の分野でなさ れて来た。

本稿は, 米国セラニーズ社 (Celanese Corp.)がこて 10 年余，世界淿さきがけて研究開発を進めて来た全く 新規な溶融液晶ポリマーからなる全芳香族ポリエステル (ポリアリレート)織維の概要を紹介するものである。こ の紻維はベクトラン(Vectran) と名づけられ，現在クラ レと同社が共同企業化を目ざして鋭意市場開発を進めて いる高強力瀻維である。

註) ベクトラン (Vectran) はセラニーズ社が登録出願 中の商標名である。

\section{2. 溶融液晶ポリマーについて}

液晶ポリマーが産業界で注目され始めたのは，米国デ

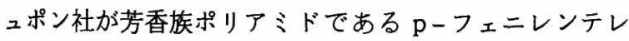
フタルアミド(PPTA)が硫酸溶液中で液晶 (Lyotropic Liquid Crystal）を形成することを見出し，乙の液晶状 態のポリマーを乾湿式紡系するととによって高強力，高 弾性䄉維を製造するととに成功し，ケブラーの名前で商 業生産を始めた（1972）ととに端を発するて 。

一方，熱溶融状態で液晶（Thermotropic Liquid Crystal) を形成するポリマーの研究が相次いでなされ た。ポリマーが液晶を形成するためには一般に剛直な分

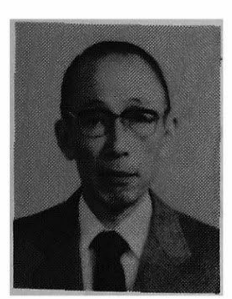

子が直線的に結合した構造をなす 必要があるが, かかる剛直棒状の

Fully Aromatic Polyester Fiber "Vectran"

(Vectran)について紹介していただいた。
高分子を熱溶融させるためには, 分子内の極性の高いポ リアミト゚よりもポリエステルの方が有用であり, 現在開 発されている溶融液晶ポリマーはその殆どがポリエステ ルである。この様な剛直な分子構造をむつポリエステル としては, 基本的なあのとしてテレフタール酸と八イド

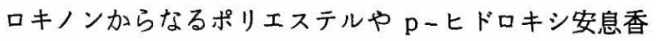
酸の自己縮合ポリエステル

$$
(\mathrm{OC}\langle\mathrm{O}\rangle \mathrm{CO}-\mathrm{O}\langle\mathrm{O}\rangle \mathrm{O})_{m}, \quad\left(\mathrm{OC}\langle\mathrm{O}\rangle \mathrm{O}_{n}\right.
$$
が考えられるが，乙れらはいずれあ分子が剛直に過ぎ， 融点が分解温度より高く $(600$ C以上) 液晶ポリマーを形 成し難い。そてで剛直性, 結晶性を若干犠牲にして液晶 形成能を損わず滛点を分解温度以下に下げ，成型加工 可能な溶融液晶ポリマーを得る多くの試みがなされた。 即5,

1. 主鎖の芳香環伅置換基を導入したり，

2. ベンゼン環とナフタレン環の様に大きさの巽なる 環を共重合して骨格構造を乱したり，

3. 柔軟なアルキル基を一部導入したり,

4. イソフタル酸の如き非直線配向性モノマーを共重 合したり

する方法が種々提案されて来た。ての様な方法で融点 （撖密には固体加ら液晶への転移温度）が $400{ }^{\circ} \mathrm{C}$ 以下 300 ${ }^{\mathrm{C}} \mathrm{C}$ 近辺迄低下し, 商業的に利用可能な溶融液晶ポリマー が次々と開発されて来たのである。

これらの中で最む初期に提案上市されたのは， $\mathrm{p}$-七 ドロキシ安息香酸 (HBA) と非液晶ポリエステルである ポリエチレンテレフタレート（PET）之を共重合させた イーストマン社の $\mathrm{X}-7 \mathrm{G}$ である゙。ユニチカが現在エン プラ用に開発中の液晶ポリマーLC- 3000 はこの流れを 引継いだものといわれている゙ 。但しとの方法によるポ

$(\mathrm{OC}\langle\mathrm{O}\rangle)\left(\mathrm{OC}\left\langle\mathrm{O}>\mathrm{CO}-\mathrm{OCH}_{2} \mathrm{CH}_{2} \mathrm{O}\right)\right.$ リエステルは高性能䄉維としては強力, モジュラスの点 で不充分な様である゙

筆者紹介 KEIZO UEDA, KURARAY Co., LTD. 株式会社 クラレ 理事・AF 事業推進部長 筆者は, 昭和 25 年 (株)クラレに入社され, ビニロン, ポリエステルの工場建設・生産・開発業務に従 事され，との間ポリエステル生産部長・特許部長などを歴任され昭和 61 年より現職。

本稿では，(株)クラレが Celanese 社 と共同で市場開発中の全芳香族ポリエステル緎維 (ベクトラン) 
又，カーボランダム社は主鎖にビスフェノールを導入 した浴融液晶ポリエステルを開発し7)，1984年ダートコ 社が射出成型用樹脂ザイダーとして上市した。睍在住友 $(\mathrm{OC}\langle\mathrm{O} \mathrm{CO}-\mathrm{O}(\mathrm{O}-\mathrm{O} \mathrm{O})(\mathrm{OC} O \mathrm{O} \mathrm{O})$ 化学工業がエンプラ用のみならず䋊維用としてす開発中 のエコノールはこのカーボランダム社の技術を心゙ースに したあのと思われる゙

一方，七ラニーズ社では1975年以来，2，6一官能性置 換基を導入したナフタレンモノマー，例えば 2,6 ーナフ タレンジカルボン酸(NDA)，2.6ーナフタレンジオール (ND)，6-ヒドロキシー2-ナフトエ酸(HNA)等のクラ ンクシャフトモノマーを用いる新規な全芳香族溶融液晶

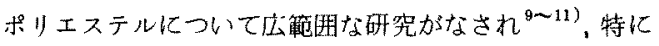
HNA ŁHBAと加らるポリエステルは，すぐれた機械 的性能(引張強度，曲げ強度，アイゾット㣫整強度等)を 有し, 又流動方向の熱線起張係数が $10^{-6}$ オーダーで韭常 に小さく成型収縮率が小さいとと，溶融状態では流動抵 机が少なく見加けの溶融粘度が低いので射出成型性がす ぐれているため，特殊な成型機や金型を必要としないて 之，融点加比較的低い(約 $\left.280^{\circ} \mathrm{C}\right)$ にす拘らず成型品の熱 变形温度が高い $\left(180^{\circ} \mathrm{C}\right.$ 以上)と，耐薬品性がすぐれて いること等，エンプラ用ポリマーとして卓越した性能を 有するととが見出された。1984年加ら同社はポリプラ スチッタ社と共同で，この HNA-HBA系ポリマーをバ クトラ(Vectra) の商標のもとに広沉な成型品分野に市 場展開を計って扣り，次世代ス一パーエンプラとして大 きな注目を浴びている。

\section{3. 溶融液晶ポリマーからの瀻維について}

上述した如く，熱溶融させるためには分子の㔄直性を 若干低下させる必要があること，又ポリマーの分子量を 增すと溶融粘度が急増するので紀糸に用いるポリマーの 分子留には限界があるとと等から，多くの溶融液晶ポリ マーは特に高強力を要求される織維用ポリマーとしては 必ずしも適当なものではなかった。即ち液鼠ポリマーの 場合，紡系時の伸長流動によって分子は容易に纎維軸方 向に配向し且つ分子間のからみが少ないので，紡系した 㵶維のモジュラスは充你大きいが，分子量に依存する強 伸度は充分とは言えなかったのである。しかしポリエス テルの場合は一般に固相重合が可能であるので, 固相重 合速度が非常に大きく，分子量の割には溶融粘度が低い 溶融液晶ポリエステルが見出されれば，紡系した緎維を 延伸することなく熱㛣理するだけで高強力高モシュラス の高性能繊維を得ることが可能となる。セラニーズ社は その10 年に扰ぶ店讵な液晶ポリマーの研究の結果, 前述の成型用ベタトラポリマー上同系統の，つまり HNA
-HBA 系の溶融液晶ポリエステルから遂に以下述へる 様な画期的な高強力，高モジュラス瀻維ベクトラン12,18) の開発に成功したのである。この HNA-HBA 系共重合 ポリエステルのポリマー、緎維, フィルム等の構造につ いては最近多くの報告が発表され，ポリマー中の HNA とHBA は完全にランダムシーケンスであることあ維 のX線回折により確かめられている

クラレにおいて李，つとに溶融液晶ポリエステル䋘維 の将来性に着目し，鋭意調查研究を進めた結果，HNA を用いる全芳香族ポリエステルか製浩技術的にも性能上 も最もすぐれているとの結諭に達し，昨年 5 月セラニズ社とベクトランの共同企業化を前提とする市場評洒之 市場開発を行うことになり，早期企業化をめざして開発 を推進している次第である。

\section{4. ヘクトランの製法}

ベクトランの原料ポリマーは前述の如く HNA-HBA 系全芳香族ポリエステルである。HNAとHBAの共重合 モル比はポリマーの融点, 溶㓲粘度, 紡系時の电綪拈 よび䋞維性能等を総合的に勘案して決められる。一般に 主銷型芳香族ポリエステルの場合，その重合はエステル 交換による縮合反心によって進められる。本系において

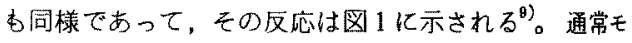
ノマーは重合に先立って無水酢酸によってアセチル化さ れる。又エステル交換反応には酶酸カリウムの如き触媒 が用いられることが多い。重合段階では酸化を防くため 反心は窒素雪囲気で進められ低粘度のプレポリマーが出 来るよ重合系は分子の配列によるドメイン形成似よりに ごり始める。その後は系内を真空にして酢酸の離脱を容 易ならしめつつ斥望の分子量まで重合を進める。

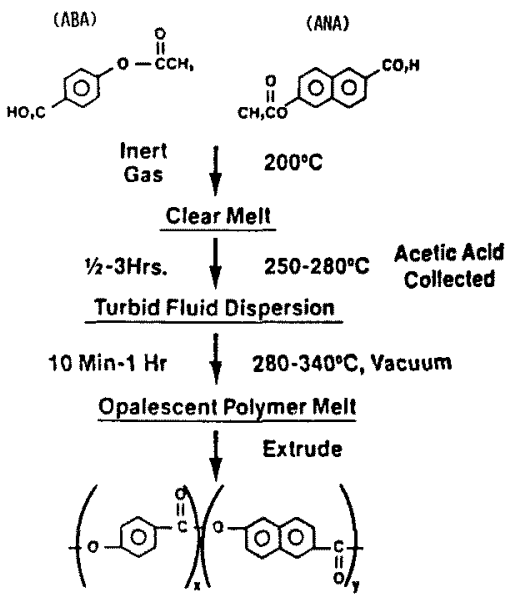

図 $1 \mathrm{HNA} / \mathrm{HBA}$ ポリマーの重合反応 
HNA-HBA ポリマーの紡系は PET 亿用いられる最 も普通の溶融紡系装置で行うことが出来る。前述した様 にてのポリマーは勭断応力下では見かけの溶融粘度が非 常に低いので, 何ら特別な押出装置を必要とせず紡系速 度も PET の場合と同じレベルである。溶融紡系した緎 維は 500 600グラム/デニール $(\mathrm{g} / \mathrm{d})$ という高モジュ ラスを有するが，紡出系を更に高温で常法により固相重 合させることによって, 強度 $20 \mathrm{~g} / \mathrm{d}$ 以上の高強力絲が 得られる。乙の場合, 液晶ポリマーの特性として紡系押 出時に分子鎖のドメインは瀻維軸方向に整然上配列して しまうので，通常の PET の様な非液晶ポリマーからな る織維の場合の様汇紡出系を熱延伸する必要は全くない。 HNA-HBA 系のポリエステルの場合はポリマーの製造 条件によって固相重合速度を著しく高め得ることが大き な特徴である ${ }^{18)}$ 。乙の様にして得られるべクトラン繊維 の内部構造モデルを図 2 亿示す。

ベクトランは以上述べた如く溶融液晶ポリマーからな る高性能繊維としてセラニーズ社が世界で初めて開発に 成功したあのであるが, 製法としては溶融重合, 溶融紀 系という最も合理的且つ経済的な方法を採用し得るとと が大きな特徵である。乙れに対し芳香族ポリアミド，例 えばケブラー（PPTA）の場合は，モノマーを有機溶媒

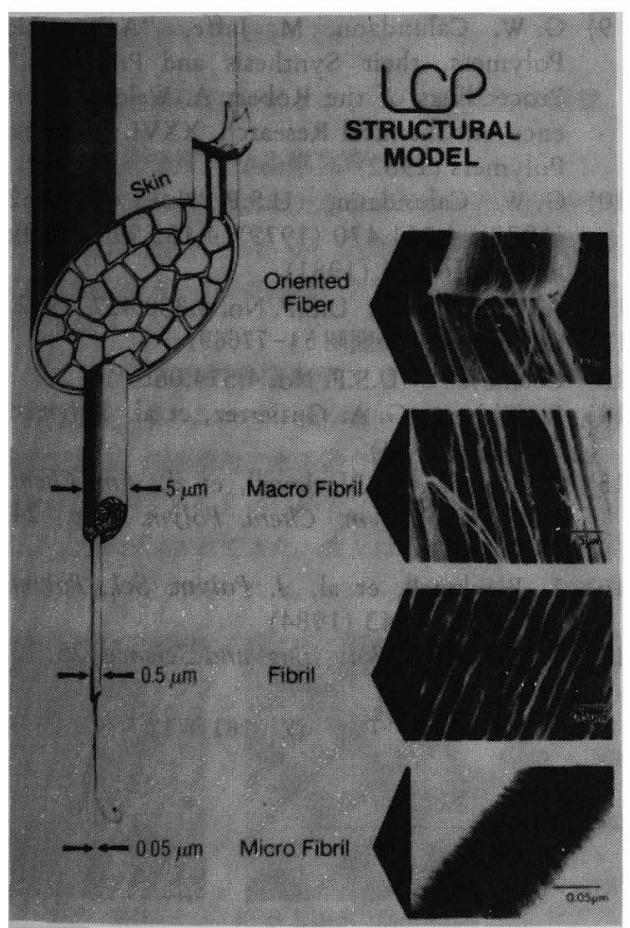

図 2 ベクトラン繊維の内部構造モデル
中で重合し, 得られたポリマーは溶剤中から分離し改め ててれを濃硫酸に溶玑して溶液液晶を形成世しめ, 水系 凝固浴中に乾湿式紡系する方法で作られると言われてお り，使用した有機溶剂及び硫酸の回収プロセスを必要と するととから，その製造工程は非常に複雑なすのになる と思われる。

\section{5. ベクトランの性能と用途}

ベクトランの基本的性質を表 1 および表 2 亿，耐薬品 性を表 3 K, 夫々アラミト繊維との対比に捛いて示した (数值はすべてクラレによる測定值)。乙れらの表からべ クトランが特に次の諸点ですぐれていることが判る。

表 1 ベクトランの基本的性能 (1)

\begin{tabular}{|c|c|c|c|}
\hline & & $\begin{array}{c}\text { ベクトラン } \\
1500 \mathrm{~d} / \\
300 \mathrm{f}\end{array}$ & $\begin{array}{c}\text { PPTA } \\
1500 \mathrm{~d} / \\
1000 \mathrm{f}\end{array}$ \\
\hline 密 度 & $\left(\mathrm{g} / \mathrm{cm}^{3}\right)$ & 1.40 & 1.44 \\
\hline 耐熱性 & $\left({ }^{\circ} \mathrm{C}\right)$ & $>400$ (分解) & $>400$ (分解) \\
\hline LOI 值 & (\%) & 37 & 42 \\
\hline 吸水率 & & & \\
\hline $20^{\circ} \mathrm{C} \times 65 \% \mathrm{RH}$ & $(\%)$ & 0 & 4.9 \\
\hline $20 \mathrm{C} \times 80 \% \mathrm{RH}$ & $(\not /)$ & 0.1 & 6.4 \\
\hline $20^{\circ} \mathrm{C} \times 95 \% \mathrm{RH}$ & $(\%)$ & 0.2 & 10.5 \\
\hline 引張強度 & $(\mathrm{g} / \mathrm{d})$ & 23.1 & 21.2 \\
\hline " & $\left(\mathrm{kg} / \mathrm{mm}^{2}\right)$ & 290 & 275 \\
\hline 切断伸度 & $(\%)$ & 3.7 & 3.9 \\
\hline 初期モジュラス & $(g / d)$ & 560 & 538 \\
\hline " & $\left(\mathrm{kg} / \mathrm{mm}^{2}\right)$ & 7055 & 6970 \\
\hline 湿潤引張強度 & $(\mathrm{g} / \mathrm{d})$ & 23.1 & 19.3 \\
\hline 湿潤切断伸度 & $(\%)$ & 3.8 & 3.6 \\
\hline 乾湿強度比 & (\%) & 100 & 91 \\
\hline 結節強度 & $(g / d)$ & 7.9 & 6.4 \\
\hline 引挂強度 & $(g / d)$ & 21.5 & 21.3 \\
\hline
\end{tabular}

註）強伸度的性能はいずれあ $80 \mathrm{t} / \mathrm{m}$ の撚りをかりた 状態で測定した。

表 2 ベクトランの基本的性能 (2)

\begin{tabular}{|c|c|c|}
\hline & $\begin{array}{r}\text { ペクトラン } \\
1500 \mathrm{~d} / \\
300 \mathrm{f}\end{array}$ & $\begin{array}{c}\text { PPTA } \\
1500 \mathrm{~d} / \\
1000 \mathrm{f}\end{array}$ \\
\hline 乾熱収縮率 & & \\
\hline $200 \mathrm{C} \times 15$ 分 & 0.1 & 0.2 \\
\hline $250^{\circ} \mathrm{C} \times 15^{\text {分 }}$ & 0.1 & 0.3 \\
\hline 耐熱老化性（強力保持率％） & & \\
\hline 乾熱 200 C× 50 時間 & 97 & 82 \\
\hline " $200^{\circ} \mathrm{C} \times 100$ 時間 & 89 & 77 \\
\hline 湿熱 $120^{\circ} \mathrm{C} \times 50$ 時間 & 85 & 77 \\
\hline $120^{\circ} \mathrm{C} \times 100$ 時間 & 79 & 43 \\
\hline 耐摩耗性(切断迄の回数) & & \\
\hline 撚合せ織維間摩耗 & 23,681 & 945 \\
\hline ユニバーサル届曲摩耗 & 670 & 277 \\
\hline 耐屈曲疲労性（強力保持率％） & & \\
\hline MIT 屈曲疲労 $130^{\circ}, 1$ 万回 & 97 & 51 \\
\hline
\end{tabular}

註）すべて $80 \mathrm{t} / \mathrm{m}$ の撚りを加けた状態で測定した。 
表 3 ベクトランの耐薬品性

\begin{tabular}{|c|c|c|c|c|c|}
\hline \multirow{2}{*}{ 葲 品 名 } & \multirow{2}{*}{$\begin{array}{l}\text { 濃 度 } \\
(\$)\end{array}$} & \multirow{2}{*}{$\begin{array}{l}\text { 澛 } \\
(\mathrm{C})\end{array}$} & \multirow{2}{*}{$\begin{array}{c}\text { 時 間 } \\
\text { (hrs) }\end{array}$} & \multicolumn{2}{|c|}{ 強力保持率(如) } \\
\hline & & & & ベクトラン & PPTA \\
\hline $\begin{array}{l}\text { 〈酸〉 } \\
\text { 壏 酸 }\end{array}$ & $\begin{array}{l}10 \\
10\end{array}$ & $\begin{array}{l}70 \\
70 \\
\end{array}$ & $\begin{array}{r}1 \\
10 \\
\end{array}$ & $\begin{array}{l}96 \\
93\end{array}$ & $\begin{array}{l}73 \\
26 \\
\end{array}$ \\
\hline 硫 酸 & $\begin{array}{l}10 \\
10 \\
10\end{array}$ & $\begin{array}{r}70 \\
70 \\
100 \\
\end{array}$ & $\begin{array}{r}10 \\
100 \\
10\end{array}$ & $\begin{array}{l}94 \\
93 \\
96 \\
\end{array}$ & $\begin{array}{l}79 \\
19 \\
40 \\
\end{array}$ \\
\hline 硝 酸 & $\begin{array}{l}10 \\
10 \\
10 \\
\end{array}$ & $\begin{array}{l}70 \\
70 \\
70 \\
\end{array}$ & $\begin{array}{r}1 \\
10 \\
100 \\
\end{array}$ & $\begin{array}{l}95 \\
95 \\
92\end{array}$ & $\begin{array}{r}60 \\
23 \\
5 \\
\end{array}$ \\
\hline リン酯 & $\begin{array}{l}10 \\
10 \\
\end{array}$ & $\begin{array}{r}70 \\
100 \\
\end{array}$ & $\begin{array}{l}100 \\
100\end{array}$ & $\begin{array}{l}93 \\
91 \\
\end{array}$ & $\begin{array}{l}46 \\
20 \\
\end{array}$ \\
\hline 酢 酸 & $\begin{array}{l}40 \\
40 \\
\end{array}$ & $\begin{array}{r}70 \\
100 \\
\end{array}$ & $\begin{array}{l}100 \\
100 \\
\end{array}$ & $\begin{array}{l}94 \\
90 \\
\end{array}$ & $\begin{array}{l}37 \\
22 \\
\end{array}$ \\
\hline $\begin{array}{l}\langle\text { イルカリ } \\
\text { 苛性ソーダー }\end{array}$ & $\begin{array}{l}10 \\
10 \\
10\end{array}$ & $\begin{array}{r}20 \\
70 \\
100 \\
\end{array}$ & $\begin{array}{r}100 \\
20 \\
10 \\
\end{array}$ & $\begin{array}{l}97 \\
66 \\
28 \\
\end{array}$ & $\begin{array}{l}68 \\
21 \\
17 \\
\end{array}$ \\
\hline $\begin{array}{c}\text { 〈溶㓝〉 } \\
\text { アセトン }\end{array}$ & 100 & 20 & 100 & 93 & 96 \\
\hline ベンゼン & $\begin{array}{l}100 \\
100\end{array}$ & $\begin{array}{l}20 \\
70 \\
\end{array}$ & $\begin{array}{l}100 \\
100\end{array}$ & $\begin{array}{l}97 \\
95 \\
\end{array}$ & $\begin{array}{l}96 \\
93 \\
\end{array}$ \\
\hline $\begin{array}{l}\text { 四塩化炭素 } \\
\text { エーテル } \\
\text { 酢エチ } \\
\text { ×タノール } \\
\text { パークレン }\end{array}$ & $\begin{array}{l}100 \\
100 \\
100 \\
100 \\
100\end{array}$ & $\begin{array}{l}20 \\
20 \\
20 \\
20 \\
20 \\
\end{array}$ & $\begin{array}{l}100 \\
100 \\
100 \\
100 \\
100\end{array}$ & $\begin{array}{l}96 \\
98 \\
98 \\
96 \\
95\end{array}$ & $\begin{array}{l}95 \\
95 \\
96 \\
94 \\
96\end{array}$ \\
\hline $\begin{array}{l}\text { エチレングリ } \\
\text { コール }\end{array}$ & $\begin{array}{l}50 \\
50\end{array}$ & $\begin{array}{l}100 \\
100 \\
\end{array}$ & $\begin{array}{r}10 \\
100\end{array}$ & $\begin{array}{l}92 \\
79\end{array}$ & $\begin{array}{l}90 \\
74\end{array}$ \\
\hline
\end{tabular}

1. 吸水率が非常に低く湿潣時の物性変化がない。

2. 耐熱老化性，耐摩耗性等の耐久性にすぐれる。

3. 耐楽品性，特に耐酸性が極めてすぐれている。

又, ベクトランは溶融紡系纎維であるにも拘らず，紡系 後の固相重合によって次の様な興味ある性質を与えられ 万。

1. 乾熱 $250^{\circ} \mathrm{C}$ 下での収縮率が $0.1 \%$ 上小さくすぐれ た寸法安定性を示す。

2. 自己消火性でいわゆるメルトドリップを抗こさず， $400^{\circ} \mathrm{C}$ 以上で分解炭化する(DSC测定によっても 明䁁な融点を示さない)。

ベクトランは上述の如くすぐれた性能を有し，製品も マルチフィラメントのみならず，チョップドストランド， パルプ, スパンラィクヤーン.モノフィラメント等種々
の形態をとり得るので，各種産業資材分野例えば，夕1 ヤコード、ベルト等のゴム筫材，ロープ，光ファイバー のテンションメンバー，摩擦材，防護材，各㮔コンポジ ット等多くの分野でその高性能が発揮されるすの上期待 される。現在既にベクトランの低吸水性，乾湿熱時の寸 法安定性，耐熱老化性，耐摩耗性，酎薬品性加多くの工 ーザーから注目され，市場開発が急ピッチで准んでおり， 早期の企業化が熱望されている。ベクトランが今後の客 融液晶ポリマーの更なる発展にささやかなが寄与し得 るならば，それは筆者によって望外の喜びである。

\section{考文献}

1) P. W. Morgan, Macromolecules, 10, 1381 (1977)

2) S. L. Kwolek, P. W. Morgan, et al, ibid, 10, 1390 (1977)

3) T. I. Bair, P. W. Morgan, et al, ibid, 10,1396 (1977)

4) W. J. Jackson. Jr, H. F. Kuhfuss; J. Polym, Sci., Polym. Chem. Ed., 14, 2043 (1976)

5) 末永純一, MOL, p. 32, 昭和 61 年 11 月号

6) D. Acierno, et al, Macromolecules, 15, 1455 (1982)

7) Carborundum 社：特公昭 57-24407

8) 住友化学工業：特開昭 58-191219

9) G. W. Calundann, M. Jaffe, "Anisotropic Polymers, their Synthesis and Properties," Proceedings of the Robert A. Welch Conference on Chemical Research, XXVI. Synthetic Polymers (1982)

10) G. W. Calundann, U.S.P. Nos, 4,067,852 (1978); 4,161,470 (1979); 4,185,996 (1980); and 4,256,624 (1981)

11) A. J. East, et al, U.S.P. No. $4,330,457$ (1982)

12) Celanese 社: 特開昭 54-776691

13) Celanese 社: U.S.P. No. 4,574,066

14) R. Chivers, G. A. Gutierrez, et al, Polymer, 25, 435 (1984)

15) R. Chivers, J. Blackwell, et al, Am. Chem. Soc. Div. Polym. Chem. Polym. Prep., 24, 288 (1983)

16) J. Blackwell, et al, J. Polym. Sci, Polym Phys., 22, 1343 (1984)

17) T. S. Chung, Poly. Eng. and Science, 26, 13 , 901 (1986)

(昭和 61 年 12 月 3 日受理) 